\title{
INTRODUCTION
}

Research depicting how religious communities foster stability and healing for members is plentiful. Particularly within 'modern' societies where isolation threatens daily existence, religious groups can provide coherence in an otherwise fragmented world (Aune et al., 2008; Bauman, 2004; Sharma and Guest, 2013; Strhan, 2015). These accounts have also explained why women participate in conservative, male dominated religious groups (Aune, 2008; Davidman, 1991; Griffith, 1997; Sharma, 2011). However, many women experience suffering in such religious settings. This article follows a strand of scholarship which moves away from a binary approach positing that Christian women either find empowerment through their churches or leave the church as a result of marginality by presenting an account of how marginalised evangelical women stay in their community despite their grievances

(Page, 2014; Page and Yip, 2017; Page et al., 2012; Sharma, 2008; Yip, 2003; Yip and Page, 2013; Winter et al., 1994).

In the evangelical community I researched, women are rendered unintelligible because of their raced, classed, and gendered bodies, on the one hand, and internal dispositions and desires, on the other. Normativity also runs along axes such as beauty and age. Women who do not meet the highly circumscribed markers of normativity are marginalised in obvious ways, such as being discouraged from leadership positions in the church, even though the church theologically supports women in leadership, as well as less obvious ways, such as being left off of work emails, for those employed by the church. More commonly, women experience marginality through social encounters; they are excluded from social gatherings or not asked out on dates by men in the church, as a result of not fitting the normative model of Christian womanhood. 
The findings presented here demonstrate that for unmarried women evangelicalism is not always uplifting, healing or supportive, and yet many women choose to stay embedded in their church. Rather than portraying these women as impervious to the concerns triggering other evangelical women's disaffiliation, I bring to the surface the very private wounds women suffer within their community, and show the emotional strategies they employ to bring about change in the church. Using Sara Ahmed's (2017: 125) definition of a 'misfit', this article probes the experience of the women whose bodies are incongruous with the world they inhabit. The participants in this study described the myriad ways they did not fit, were misunderstood, and invisibilised in the evangelical context. As one woman demanded to know: 'What about us? Are we then to be de-valued by the church?'

After outlining my theoretical and methodological approach, I will describe the normative figure of an ideal evangelical Christian woman. Subsequently, I will interrogate what happens to women who are unable or unwilling to inhabit these norms in their prescribed manner, and how this marginality positions them on the periphery of church life. One woman explained that she resides on the 'edge of the inside', a very specific location that is neither at the centre nor outside it. Next, I examine the emotions produced through marginality, including loneliness and anger. These emotions moved between bodies, and, more importantly, they moved bodies (Ahmed, 2004). Finally, I will parse out the intimacy between emotions and focus on the productive work of hope as an 'expectant emotion' (Ngai, 2005: 209). I demonstrate how hope nurtures emotions such as pain, anger and loneliness, providing women with a future-oriented attachment to the church, and bolstering them as they seek to change the normative framework within their church. 


\section{BACKGROUND: THOSE WHO LEAVE AND THOSE WHO STAY}

Research that documents Christian women's contentment with traditional gender roles fails to account for the dissatisfaction and frustration that many of my participants describe. R. Marie Griffith's (1997: 163) study on conservative evangelical women's prayer groups in the US finds that women respond to inequality by embracing subservient roles, which help the 'relatively powerless' to recover their power. Similarly, other scholars of conservative Christian women argue that religion empowers women (Brasher, 1998; Gardner, 2011). Although moving away from the empowerment model, research on Orthodox Jewish women (Avishai, 2008; Fader, 2009; Taragin-Zeller, 2014) and Muslim women (Deeb, 2006; Mahmood, 2008) examines how piety shapes women's religious selves, rather than focussing exclusively on how religious women suffer in conservative religious traditions.

When it comes to evangelical Christianity, Aune (2008) reports that evangelicals lost three times more women than men between 1989 and 2005, and that women are disaffiliating, pro rata, at a higher rate in evangelicalism than any other Protestant group in the UK. The women most likely to disaffiliate, according to this research and similar studies, are those who are career-driven, feminist, and sexually active (Sharma, 2008; Woodhead, 2008). These claims also raise a particular predicament for my research findings as the women in my study, who fit the categories of 'most likely to leave', are staying and actively participating in church life. Ingersoll's (2003: 136; 2002) study of evangelical Christian women in the US appreciates the difficulty many women face in a religious group with conservative gender norms and acknowledges that 'they stay despite tremendous turmoil'. Relatedly, Chong (2006: 711), in her ethnographic study of South Korean evangelical women, underscores the complicated dynamic 
of staying and suffering 'psychic injury'. These accounts create a fuller picture of how women experience evangelicalism as oppressive and emancipating, wounding and healing, exclusive and embracing-- all at once (Aune, 2002; Aune et al., 2008; Page and Yip, 2017; Sharma; 2011). In its plenitude, this body of scholarship, along with the stories presented here, allow for a broader, more universal question to emerge: why does anyone stay in an environment that constrains and limits them?

\section{METHODOLOGICAL AND THEORETICAL APPROACHES}

This article stems from a larger study in which I analysed evangelical women's religious and gendered identities, and embodied practices. I conducted ethnographic research with 33 unmarried evangelical women between the ages of 22 -38 over 15 months. Most attended a large, charismatic Anglican church in London, which I refer to as Crossroads, ${ }^{\mathrm{i}}$ and half of the women worked for the church at the time our interview took place. All identified as heterosexual and most of the participants were middle class, as is reflective of evangelical Anglicanism in the UK (Evangelical Alliance, 2017; Guest et al., 2017; Strhan, 2015). Of the 33 women I interviewed, the majority (25) are white, two are Asian, and six are black or mixed race. These racial demographics also mirror that of Anglicans nationally, who are 96\% white (The Archbishops' Council Report, 2014). In this article, I draw on in-depth interviews, as well as participant observation data gathered through a monthly Bible study group that I joined, and events I attended through a women's leadership network called Women Rising (WR), which met at Crossroads. 
My decision to research evangelical women in London derives from my personal experience growing up in evangelicalism. I occupied an 'insider' position as a middle class, white woman, who was a practicing evangelical for most of her life. This position opened up several advantages; I was granted access to participants easily, and my familiarity with Christianity generated a socially embedded knowledge which eased my interactions with participants. At the same time, having left Christianity a decade prior, I also occupied an outsider position. In addition, my racial and class positionality undoubtedly shaped my interactions with participants of colour and those from working class backgrounds. Thus, my positionality bears on the research findings, especially around the topic of marginality, and I have taken a reflexive stance to augment this limitation, ceding my similarities with my research participants and writing about their faith lives as expansive beyond my own (Best, 2003).

Theoretically, my research is underpinned by a lived religion approach, which attends to believers' everyday practices as modes of religious life (Ammerman, 2014; Hall, 1997; McGuire, 2008; Orsi, 2002). By approaching religion as lived, I consider the body as a vehicle through which religion is practiced. Rather than only asking my participants what they believed, I inquired as to how these beliefs informed their lived experiences of being in their bodies, how beliefs directed their movements through the city, structured their social relations, and governed their sexual practices. The second theoretical framework guiding this article and the larger study is a Butlerian (1997) approach to subject formation. I analyse the formation of the subject through processes of exclusion, which enables certain identities to emerge as others are repudiated (Hall, 2000: 15). I build on previous scholarship that highlights unmarried women's marginal status in the evangelical context (Aune, 2008; Sharma, 2011), and I advance the argument by showing that exclusion also runs along intersecting axes of race and class (Brah and 
Phoenix, 2004; Crenshaw, 1989; hooks, 1987). Thirdly, I draw on theoretical literature examining affect and emotions to frame my findings. I disentangle evangelical women's different emotions in order to understand the relationships between them and interrogate how particular emotions effect women's involvement with their religious community.

\section{FINDINGS}

\section{The Ideal Christian Woman}

The first time I attended WR, I met Jessa, a paradigmatic example of Christian womanhood. In her late twenties, Jessa was white, attractive and thin with long hair and stylish clothes. She fit the ideal Christian woman, as described to me by another participant: "Wholesome yet hot, strong yet submissive'.

The clearest descriptions of an ideal Christian woman came when I asked my participants directly. They defined her in formulaic precision.

[They're] all quite meek and always had loads of kids running around. Patient, like a very mature attitude I think. [There is] just no one like me. I think calm is a word that I would not associate with myself and I would associate with people I look at that are quite good examples of a good Christian woman. And they dress very formally, not too revealing, don't draw attention to themselves. They put everyone apart from themselves first.

The above quote is from Heidi, a black, middle class woman in her early thirties who worked for a charity and was single again after having been briefly married. Heidi interpreted normativity through bodily comportment: the stilled body that expressed an internal calmness; the body 
modestly adorned; the selfless woman, who conveyed her humility through her bodily conduct. Although Heidi admitted she failed to meet the internal attenuations of a Christian woman, she did not mention race, which I attribute to how her class positionality intersected with race, making race a less obvious category of marginality for her. Jacqui, another middle class black woman, described the normative figure as 'blond, thin, a little artsy on the side, something with kids, very Christian, not strong, ambitious, or career oriented'. As Jacqui demonstrates, the ideal Christian woman was formed by intersecting markers of whiteness, middle classness, and femininity (Frankenberg, 1993; Reay et al., 2011; Skeggs, 1997). Other participants said the ideal woman 'works at a charity', 'only has one or two glasses of wine when she goes out', and 'is powerful but not too powerful'.

Barbara Ann was also at the WR event the first night I attended. She is a white, middle class woman in her late twenties, and scoffed at the young 'Scandinavian Barbie' that men in the church preferred, noting her inability to live up to these physical standards. Her descriptions of the normative Christian woman's outward appearance reveal that beauty also intersects with race, class, and gender to stake out a 'socially desirable femininity' (Griffith, 2004; Jackson and Lyons, 2013: 240). In other social gatherings, women would complain about the pressure they felt to dress well and look good when attending church (Sharma, 2011).

In this evangelical context, intelligibility was often conferred via romantic interest from men, which, if it led to marriage, made it easier for women to access leadership roles in the church via their husband's position. A few women told me drily that it would be easier to marry a male vicar than try to fight for a leadership position on their own. Such comments, even if said sardonically, reveal the myriad benefits that women gain from male recognition in the church. Barbara Ann described her personality as ambitious, strong and feisty, which further prevented 
her from being seen by men. She reported that she had never been asked out by a Christian man and suggested that it was because she was not a 'cool chill girl' as she challenged sexism in the church. In between tears, Barbara Ann shared the pain of feeling invisible and unwanted by men, to be the problem that drove men away, by pointing out the problem of sexism (Ahmed, 2010: $65)$.

Several other women I interviewed reported feeling 'unwanted' by men in the church due to their personalities, which contrasted sharply with evangelical feminine norms of compliance, passivity, and calmness. The violation of these norms meant that men deemed certain (opinionated) women as too assertive and strong. Indeed, at least four different women mentioned the word intimidating during our interviews. These women were told directly by men that they were intimidating and encouraged to 'tone down' their personalities. Vanessa, a working class woman in her late thirties, described feeling invisible to men in Christian circles. She experienced invisibility through two interwoven vectors: first, her personality ('strong') did not fit with the normative woman ('submissive'); second, as a mixed-race woman, she did not fit with the atmosphere of whiteness that circulated in her evangelical congregation (Anderson, 2009; Frankenberg, 1993).

I have a mirror, I know what I look like, I go out and am hit on by hundreds of guys, and I don't mean in one night. But in church I have never even been asked for a coffee. That for me was a big eye opener. Just like, there's something not right. I remember saying to the pastors: people are quite racist, they will be your friend, and they will talk about how beautiful you are, but they wouldn't take you home to mum and dad. It's that kind of thing. That is something I struggled with quite a lot for a long time. But then I just got to 
a point [where I thought] actually I don't want any of these people, so why does it bother me?

Vanessa made sure to clarify that the church did not explicitly bar people of colour, but nevertheless the abundance of 'white, middle class, double barrel name' congregants populating Crossroads meant that 'for black people when they go into the church, unless they are in good [clothes] and stuff they just feel they don't fit because all they are seeing is a lot of white middle class'. Vanessa testifies to how race and class intersect with gender to structure social interactions within her evangelical community creating what Puar (2001) calls the 'racialised somatic norm', which in turn constructs the conditions for Vanessa's marginality (Ahmed, 2012; Frankenberg, 1993; McClintock, 1995; Valentine, 2007; Skeggs, 1997). Thus, through relational encounters with men, Vanessa's body was racially marked, and read as undesirable (Ahmed, 2017).

As already reported by other researchers of Christianity, evangelical women are expected to fill the normative roles of wife and mother (Aune, 2002, 2008; Sharma, 2011). Several women, still single in their thirties, received reminders that they were falling behind. Rachel, aged 31, became a Christian in her early twenties. When I met her, she worked for the church, and although she reported overall satisfaction with her church community, she had a few frustrations with how women were meant to behave. She reported:

I think there's that archaic stereotype of being the good wife, as a woman all you're expected to be is a wife and a mother and be quiet and subservient and I completely push against that. A group of people once told me on a church course that because I was over the age of 25 I had gone past my Christian sell-by date so I should look forward to a life of spinsterhood and just being a charitable person who gave all my free time to the church. 
This comment reveals overlapping markers of normativity: internal dispositions such as subservience and calmness, and externally recognisable modes of femininity communicated through the roles of wife and mother. Furthermore, Rachel highlights that age also serves to demarcate the ideal Christian woman as women are labelled deviant (a 'spinster') if they remain unmarried after a certain age.

Women's marginality also operated along class lines. Crossroads is located in an affluent area of London, and most congregants are middle to upper class. For the three women in my study who identified themselves as working class, markers of class presented themselves through embodied habits, such as the double kiss greeting. I experienced the physicality of class when I arrived at Mia's house for our interview. We exchanged an awkward greeting as I went to hug her and she offered a kiss on my cheek. This social interaction opened up a conversation about customs, greetings, and social class. Mia told me about first attending Crossroads:

I found it very exclusive, very cliquey, because of where it is geographically naturally it is going to attract a certain type of person: very posh, etcetera. Which is fine, I like posh people, I like people that aren't posh. But I just found it sort of forced, particularly the greeting of the double kiss because I just, I have such a problem with it, even though I $d o$ do it, I just think it's so poncey. And I remember one time at [the church retreat] I was with a group of four girls and they were all of that ilk, and I was sort of trailing behind, I was just texting or something. And they met this guy and they just said hello, double kiss. One, second one, third one, fourth one [all did it], and I was like, "Hey, I'm Mia!”

Mia testifies to how class is performed and lived through the body (Skeggs, 1997). Additionally, she locates herself as marginal in relation to middle and upper class Christians, evidenced 
through distinct linguistic clues such as identifying other people as 'posh' and 'of that ilk'. Jennifer also mentioned the double kiss:

There is a particular way of speaking, and it's often quite subtle. Like, when people say hello for the first time, they usually do the double cheek kiss thing. Where I come from, no one would ever do that! I suppose little social interactions like that. When you go to particular schools and move in particular circles, there is a way of speaking that can come across as fairly cultivated. I'm sure part of that is my own insecurities, and my own judgements of other people ... But it is something that I am aware of and often makes me feel quite uncomfortable.

Both Mia and Jennifer demonstrate how the double kiss, as a symbol of middle classness, maps onto bodies and is articulated through the body. The gesture itself draws up lines of inclusion and exclusion, and is a mechanism by which value is attributed to some bodies and withheld from others (Skeggs, 2004: 20; Skeggs, 1997). By speaking differently and not partaking in the double kiss Mia and Jennifer are positioned as not- posh, and they manifest their marginalisation through the body-- Mia by 'trailing behind' the others, and Jennifer by 'feeling uncomfortable'. Of course, as described earlier, class norms do not operate independently of race or gender. Instead, they intersect in such a way that when women perform middle classness, such as speaking a certain way, they simultaneously perform whiteness and socially-valued forms of femininity (Hill Collins and Bilge, 2016; Frankenberg, 1993; Puwar, 2001).

Thus, the good Christian woman is composed of both internal dispositions and external bodily markers. By describing the contours of normativity and positioning themselves in relation to the ideal woman, my participants shed light on a figure crafted through exclusion. Power operates through a 'matrix of intelligibility', whereby certain subjects gain intelligibility at the 
same time that others are rendered marginal (Butler, 2007: 24). In this sense, exclusions are instrumental insofar that through their circumscription the periphery defines the centre (Hall, 2000; Mohanty, 1998). The next section will explore the affective dimensions of living on the periphery in more depth.

\section{Experience and Affect}

Affect arose frequently throughout my fieldwork with unmarried evangelical women; after all, the charismatic church they attended promotes an emotional connection with God. I recall the bodily articulations of my participants' pain: the lowered eyes, the hunched shoulders, the angry words that spewed out of mouths when talking about not being seen, being rendered unseeable (Ahmed, 2010; Anderson, 2009).

Vicky, a white working class woman in her mid-thirties, put into words the affective toll of staying actively involved with her church. She explained that in the evangelical context her ambition and drive was considered intimidating. I asked if that caused her to question her faith.

It makes me angry, it doesn't make me question my faith. Because I think there are a lot of stupid things we [as Christians] do. I have strong opinions: I think that homosexuality is fine, I get angry that the church doesn't agree, but it doesn't make me feel angry at God, it makes me feel angry at the church.

Being identified as 'intimidating' provoked Vicky's anger; she was assigned an identity that she did not choose and did not want, signalling a process of misidentification (Ahmed, 1998: 117; Skeggs, 1997). Similarly, Barbara Ann recalled being labelled an 'angry feminist' when she engaged with fellow Christians on issues of gender equality in the church. 
If I'm too angry when I approach these things, then it's not helpful for me to step in, because I'll just be labelled an "angry feminist" and also, that de-legitimizes any point that I have, if I become the" angry feminist".

When I asked her if being labelled this way, usually by Christian men, ever caused her to question her faith she quickly replied: 'No. It doesn’t make me not believe in God it makes me not believe in men. It makes me not believe in men at all.'

As an emotion, anger requires both an occasion and an object; in the examples provided by Vicky and Barbara Ann, the occasion was sexism in the church (and the resulting identification as 'intimidating'), and the objects were other Christians, rather than God (Baier, 1990). Unlike low-grade emotions such as irritation (Ngai, 2005), anger is infused with energy, and 'its object is change' (Lorde, 1981: 282). Both Vicky and Barbara Ann strategically directed their anger towards that which is changeable - men in the church and church leaders - instead of God, who they believed to be an un-changeable, all-powerful being. This relocation of anger served as an affective strategy which, accompanied by the hope that people could change, strengthened women's resolve to stay in the evangelical community.

Other women reported loneliness at the margins. Jennifer recounted not fitting in at church because she was identified as a working class woman. She described exclusion as isolating and said: 'It can feel quite lonely. When I think about the people I'm good friends with, no one comes from the kind of background I come from.' In a later conversation, Jennifer told me about meeting another working class woman at the church, and the relief that washed over her body as she finally found companionship in the margins. 
When women do not find this companionship, feeling like a misfit can bleed into a deep sense of not belonging (Emmerson and Smith 2001; Hopkins 2007; Sharma and Guest 2013; Tranby and Hartmann 2008). Some women managed this feeling by not investing very much in the church even if they continued to attend. A woman from the Bible study group I joined, Tina, described being cast to the periphery because of her intellectual and political interests, as well as being a single woman over age 30 .

I think being single I feel I don't fit in. I think there are a lot of people that get married and then they become very different and it's quite a lonely place to be, as a single person. That's one reason why I don't put in as much. I go for my relationship with God, rather than to meet people and to engage with people.

By coming in and going out quickly from church, Tina hovered in the background and avoided social encounters. She externally manifested her internal feeling state of isolation, and, just like Vicky and Barbara Ann, she redirected her energy towards fostering her relationship with God whilst simultaneously distancing herself from other Christians.

Similarly, Heidi, a 40-year-old black, middle class woman told me: 'I like to try and be on the periphery I think'. When I asked her what that felt like, she responded:

I feel like I shouldn't really be there, or I should be there with a male figure and he should then be my husband because the first thing they'll then ask you is so how's your dating life going? 
Heidi's single-status took on a life of its own during our interview and became an 'it' ('I don't want it to be highlighted'), like a material defect that must stay hidden. Heidi experienced singleness as a concealed injury that moved her towards 'the outskirts', demonstrating how unintelligibility works insidiously by lodging a sense of defectiveness into its bearers, and steering them towards the margins, the outside of the inside.

Simone, a woman who did not fit because of her support for feminism and her single status, also told me she resided 'on the outside' and felt like 'an observer'. She elaborated:

I just think it's really important if you are going to be a Christian [to know that]: One, it's really lonely and it's really hard to do stuff when you are by yourself, beliefs die you know.

Simone located herself on the periphery and her strategy -- to not invest much in the church and participate minimally-- mirrored other women's strategy to attend the church but remain in the shadows, investing in their connection with God instead of other Christians, who established and upheld the normative boundaries.

From this place of marginality, women sometimes questioned themselves and their legitimacy as subjects. Lindsay was one such case. She met most of the markers of the ideal Christian woman: white, blond, attractive, modest, friendly, and middle class. Much to my surprise, during our interview she disclosed an internal struggle between what a Christian woman should desire, and what she actually wanted. In her early thirties, Lindsay worked in a successful corporate job, and admitted to not desiring marriage or children yet. I asked her how this disjuncture made her feel: 
Well raw because its personal and not that the stakes are high, but I feel quite passionate about it, and also frustrated. I think I want to work out what the answer is and if I am doing this wrong. Why do I feel the way that I feel, why do I view the things that I do? Is it because that's the way I've been conditioned culturally but that's actually not naturally what I should be like? I've just learned to behave in a certain way, I've learned to be competitive, I've learned to be ambitious. I've learned to want to be the best at everything, better than boys [...] Am I doing this right? -- I sometimes feel like that.

Lindsay's ambitions served her well in the workplace but hindered her in the evangelical context, causing her to question if her dispositions were 'natural', and indicating another low-grade, durational emotion that arises at the site of marginality: self-doubt (Ngai, 2006).

Issy, another participant, wanted to be seen as a sexual subject. She is a white, middle class woman aged 24 , and she told me: 'I feel it would be a taboo to talk to people and say: I want sex. Because I feel like I shouldn't want that.' Her aspiration for sexual subjectivity and her reflexive awareness that her internal desires violated those of a good Christian woman caused her to feel frustration and shame. Moreover, similar to Lindsay, Issy not only questioned her desires -- she questioned herself, plunging her into an endless state of self-doubt.

Continued marginality and the desire for normativity often produced fatigue. One woman told me: 'Sometimes I'm very tired, I can't go on.' Similarly, Barbara Ann felt compelled to remain actively involved with her church at the same time as she faced 'quite deep-rooted pain'. What did it feel like to not fit in, to challenge the limits of recognisability? 'It's tiring; I'm very tired', she replied. According to these accounts, women who are positioned as misfits are barred access to the normative centre of evangelical life. The margins are marked by pain, loneliness, 
anger, self-doubt and fatigue. By themselves, these emotions might lead women to leave the church or remain at the margins indefinitely; when coupled with hope, however, women utilise these affective states to change the church, as the next section will explore.

\section{Hope's Work}

A subset of evangelical 'misfit' women strategically drew on their marginality to alter the architecture of intelligibility within the church. In order to do so, they combined their anger, loneliness, and pain with a more fortifying emotion: hope. These emotions nourish each other; hope needs anger for the fuel to wish one's circumstances to be otherwise, and anger needs hope for the patience to wait until change arrives (Baier, 1990; Lorde, 1981). The process of using anger to generate change, or at least try to generate change, requires an optimistic belief that things are improving and that conditions are changeable. Without a hope that animates and motivates, continued marginality could become 'an act of petrification' (Riley, 2000: 117). Hope, on the other hand, diverts attention away from present circumstances by emphasising the future (Bloch, 1995; Mussell, 2017; Ngai, 2005; Potamianou, 1996).

I asked one middle class black woman, named Susan, aged 34 why she stayed in an environment where she continually felt marginalised. Susan replied: 'I want to stay to push the boundaries.' Although recently married, she had spent years suffering the wounds of unintelligibility incurred through being single, female and racialised. Instead of remaining in the margins, however, Susan combined anger with hope and persisted in the Christian community, eventually became the first woman of colour at a large Christian organisation. Susan's story reveals hope as an attachment - not only to the evangelical community but to a world configured differently (Berlant, 2011). 
Vicky similarly combined anger with hope to start the feminist group Women Rising.

What I found really frustrating, when I joined the church at 26 , and was identified as an all-star with heaps of potential, so amazing, was that time and time again I would see men join the church at the same level and they would get put straight with our church warden. They would be taken to rugby matches, they would be supported ... I think, my dream is that people aren't in the position that I was in, which is to have so much potential to change the world and be given no support to get there. I am from a family which is very working class, neither of my parents graduated from high school, how am I supposed to reach the upper echelons of society and business if no one is supporting me to get there, because it is a boy's club?

Vicky actualised her 'dream' -- that women receive support to reach leadership positions_-by creating WR. But in order to do so in the first place, she needed hope, which expanded the horizon of possibility to include a future where women were treated equally (Ahmed, 2010). The path had not always been easy, however, and Vicky openly shared about the resistance she encountered, including being branded a feminist and 'feisty', both negative terms in this context. Instead of contesting these labels, Vicky embraced them and built WR on the discursive site of injury (Butler, 1997; Brown, 1993). In fact, to inaugurate WR, Vicky organised a panel at the church retreat titled, 'Was Jesus a Feminist?'. Identifying Jesus as at difficult figure, a feminist, thus, alleviated the sting of a word meant to harm. Furthermore, the founding of the group represented the productive work of emotions, as anger provided the energy to organise a group of women, and hope the succour to endure. 
Jennifer, who described her frustrations as a working class woman in the church, also felt motivated to make Crossroads more inclusive and 'more aware of the massive class issue'. She reported:

And that's part of the reason I stick it out and try to get involved with everything I can because if a working-class woman is more visible, it might make other people in similar situations feel a little bit more comfortable.

In other instances, Jennifer pointed to signs that Crossroads was becoming more inclusive, such as when the church retreat featured an almost equal number of male and female speakers. These occurrences nurtured Jennifer's hope that conditions were changing and provided her with the fortitude to stay at the church. Both she and Barbara Ann started working full time for Crossroads halfway through my fieldwork. I questioned how they could invest even more in the church whilst maintaining serious grievances with the limitations placed on them. Barbara Ann told me:

I think that were called into community. I do believe that is something that's emphasized in the Bible, and I believe that we should be part of the change, I think that's really important.

By using the word 'we', Barbara Ann signalled her marginal positionality. She rooted her efforts for change in this position, and, by asserting herself as non-normative she established her identity through difference (Brown, 1993; Connolly, 1991; Riley, 2000). Like Jennifer, Barbara Ann 
deeply believed that the conditions were changeable and that they were in the process of changing.

Jacqui, who had often mentioned her frustration with a key few issues with the church the lack of diversity, the lack of women in leadership, and the evangelical approach to sex - also held to a belief that church members were shifting their attitudes. I asked her if these frustrations ever caused her to consider leaving the church, and she told me: 'No, because the church leaders are trying to get a few more women'. Other women assured me that Crossroads' leaders were 'working on it' and were 'trying' to increase racial and gender representation. In regard to the paucity of female speakers, one participant confidently stated: 'The leadership are desperate for that not to be the case'. Alex, a mixed-race woman aged 36, brought up the lack of diversity among church leaders. I asked her to explain more.

It's not a personal pressing issue because I've got good relationship now and I've got a good network of people I can go to. But for those people who feel the need to go to somebody in leadership to talk about their stuff it's really disproportional not having any people of colour, of any colour and not having any women. And I know in particular Crossroads is trying like crazy to address it. But (pause) I was talking to a friend of mine, having a coffee with her, and there was a ripple feeling of: is there a racism issue here? I personally don't feel anything like that ...

Without a belief that Crossroads was 'trying like crazy to address [diversity]', Alex might have left the church. Without the presence of hope, her frustration may have translated into an urgent demand for change (Potamianou, 1996: 59). Events that might have caused a snap for some, or finally stimulated their exit, instead were tempered by hope, which aided women's re-investment 
in the church (Ahmed, 2017). Thus, by coupling anger with hope, an alternative horizon emerged, in which women continued to work for change in the church, a horizon which kept them from leaving.

\section{CONCLUSION}

This article has explored how single evangelical women are situated as marginal, and how they experience and embrace this injurious location. I have demonstrated that women who are marginalised do not always leave, despite what previous studies report. Some stay, and in probing how and why they stay, we expand our capacity to understand why any of us stay in environments that limit us. These testimonies affirm the abiding desire in all subjects to embrace socially recognised categories of identity, to embrace legibility (Butler, 1997).

The social context that single evangelical women inhabit determines the bounds of normativity and arbitrates their legitimacy as subjects. Participants described in very specific terms the normative evangelical Christian woman, and in so doing they located themselves at the margins, and elucidated how unintelligibility is embodied, felt and transitively relayed. One of the key emotions that evangelical misfit women felt was anger. Anger at being located on the periphery provoked defiance towards the centre, at times landing on the ideal figure of a submissive and agreeable white, middle class Christian woman, and other times settling on church leaders, but never on God. Marginality, or identity as procured through being a 'not' both consolidated women's position on the outside and insidiously tied them to normativity through a logic of relationality (Ahmed, 2017; Brown, 1993). 
I conclude by casting hope into question. I argue that in examining why women stay in an evangelical community that renders them marginal, we must look beyond anger and suffering and interrogate the productive effect of hope. This article has demonstrated hope's work: it sustains the subject at the margins and secures her investment in the church. But is hope only that which sustains, or does it also imprison, holding women in abeyance for a future that may never come? (Ahmed, 2010; Berlant, 2011; Munoz, 2009, Jameson, 1971). In addition to subsistence, we might consider hope to be an emotion which arrests change and leaves its subject waiting (Bion, 1961; Potamianou, 1996). With the decline of the established church and the rise of 'no religion' in the UK, it is imperative that Christian leaders attend to another question: what happens when hope runs out?

For now, evangelical women remain angry, yet wilfully optimistic; they aspire towards a future where all women count in evangelicalism and they live as if that future is on its way.

\footnotetext{
${ }^{\mathrm{i}}$ The names of participants, churches and church groups have been changed for confidentiality.
}

\section{BIBLIOGRAPHY}

Ahmed S (1998) Differences That Matter: Feminist Theory and Postmodernism. Cambridge, UK: Cambridge University Press.

Ahmed S (2004) Affective economies. Social Text 22 (2): 117-139.

Ahmed S (2010) The Promise of Happiness. Durham: Duke University Press.

Ahmed S (2012) On Being Included. Durham: Duke University Press. 
Ahmed S (2017) Living a Feminist Life. Durham: Duke University Press.

Ammerman NT (2014) Finding religion in everyday life. Sociology of Religion, 75(2), 189-207.

Anderson B (2009) Affective atmospheres. Emotion, Space and Society 2(2): 77-81.

Archbishops' Council Report (2015) Everyone counts: Diversity audit key findings. London: The Archbishops' Council, Research and Statistics, Central Secretariat, Church of England.

Aune K (2002) Single Women: Challenge to the Church? Milton Keynes: Paternoster Press.

Aune K (2008) Evangelical Christianity and women's changing lives. European Journal of Women's Studies 15(3): 277-94.

Aune K, Sharma S and Vincett G (2008). Women and Religion in the West: Challenging Secularization. Farnham: Ashgate.

Avishai O (2008) "Doing religion" in a secular world: Women in conservative religions and the question of agency. Gender \& Society, 22(4): 409-433.

Baier A (1990) What emotions are about. Philosophical Perspectives 4: 1-29.

Bauman Z (2004) Identity: Conversations with Benedetto Vecchi. Cambridge UK: Polity Press.

Best A (2003) Doing race in the context of feminist interviewing: Constructing whiteness through talk. Qualitative Inquiry, 9(6): 895-914.

Bion WR. (1961). Experiences in groups and other papers. London: Tavistock Publications. [Reprinted London: Routledge, 1989; London: Brunner-Routledge, 2001.]

Bloch E (1995) The Principle of Hope: v. 1 (Reprint edition). Cambridge, Mass: MIT Press.

Brah A and Phoenix A (2004) Ain't I a woman? Revisiting intersectionality. Journal of International Women's Studies, 5(3): 75-86.

Brasher B (1998) Godly Women: Fundamentalism and Female Power. London: Rutgers University Press.

Brown W (1993) Wounded attachments. Political Theory 21(3): 390-410. 
Butler J (1997) The Psychic Life of Power: Theories in Subjection. Stanford, CA: Stanford University Press.

Butler J (2004). Bodies and Power Revisited. In D. Taylor \& K. Vintges (Eds.), Feminism and the Final Foucault. Urbana: University of Illinois Press.

Butler J (2007) Gender Trouble. Oxon, UK: Routledge.

Chong K (2006) Negotiating patriarchy: South Korean evangelical women and the politics of gender. Gender \& Society 20(6): 697-724.

Connolly W (1991) Identity/ Difference: Democratic Negotiations of Political Paradox. Ithaca: Cornell University Press.

Crenshaw K (1989) Demarginalizing the intersection of race and sex: A Black feminist critique of antidiscrimination doctrine, feminist theory and antiracist politics. University of Chicago Legal Forum, (8).

Davidman L (1991) Tradition in a Rootless World: Women Turn to Orthodox Judaism. Oxford: University of California Press.

Deeb L (2006) An Enchanted Modern: Gender and Public Piety in Shi'i Lebanon. Princeton: Princeton University Press.

Emmerson S and Smith C (2001) Divided by Faith: Evangelical Religion and the Problem of Race in America. Oxford: Oxford University Press.

Evangelical Alliance (2017) “2 $2{ }^{\text {st }}$ Century Evangelicals Report."

Fader A (2009) Mitzvah Girls: Bringing up the Next Generation of Hasidic Jews in Brooklyn. Oxford, UK: Oxford University Press.

Frankenberg R (1993) White Women, Race Matters: The Social Construction of Whiteness. London: Routledge.

Gardner C (2011) Making Chastity Sexy: The Rhetoric of Evangelical Abstinence Campaigns. Berkeley: University of California Press.

Griffith RM (1997) God's Daughters: Evangelical Women and the Power of Submission. London: University of California Press.

Griffith RM (2004) Born Again Bodies: Flesh and Spirit in American Christianity. Oakland: University of California Press. 
Guest M, Page, SJ \& Taylor Y (2017) Introduction: class and Christianity. Sociological Research Online, 22(1): 16.

Hall DD (1997) Lived Religion in America: Toward a History of Practice. Princeton: Princeton University Press.

Hall S (2000) Who needs 'identity’? In: du Gay, Paul, Evans, Jessica and Redman, Peter (eds) Identity: A Reader. London: SAGE Publications.

Hill Collins P and Bilge S (2016) Intersectionality. Malden: Polity Press.

hooks b (1987) Ain't I a Woman? Black Women and Feminism. London: Pluto Press

Hopkins P (2007) Young people, masculinities, religion and race: New social geographies. Progress in Human Geography 31(2): 163-177.

Ingersoll J (2002) Against univocality: Re-reading ethnographies of conservative Protestant women. In: Spickard J, Landres S and McGuire M (eds) Personal Knowledge and Beyond: Reshaping the Ethnography of Religion. New York: New York University Press.

Ingersoll J (2003) Evangelical Christian Women: War Stories in the Gender Battles. New York: New York University Press.

Jackson S and Lyons A (2013) 'Girls' new femininity refusals and 'good girl' recuperations in soap talk. Feminist Media Studies, 13(3)

Mahmood S (2008) The Politics of Piety: The Islamic Revival and the Feminist Subject. Princeton: Princeton University Press.

McClintock A (1995) Imperial Leather: Race, Gender, and Sexuality in the Colonial Context. New York: Routledge

McGuire M (2008) Lived Religion: Faith and Practice in Everyday Life. Oxford: Oxford University Press.

Mohanty CT (1988) Under western eyes: Feminist scholarship and colonial discourses. Feminist Review 30(1): 61-88.

Mussell S (2017) Critical Theory and Feeling: The Affective Politics of the Early Frankfurt School. Oxford: Oxford University Press. 
Ngai S (2005) Ugly Feelings. London: Harvard University Press.

Orsi RA (2002) The Madonna of 115th Street: Faith and Community in Italian Harlem, 1880 1950. New Haven: Yale University Press.

Page SJ (2014) The scrutinized priest: Women in the Church of England negotiating professional and sacred clothing regimes. Gender, Work and Organization, 21 (4): 295- 307.

Page SJ and Yip AKT (2017) Gender equality and religion: A multi-faith exploration of young adults' narratives. European Journal of Women's Studies, 24(3): 249-265.

Page SJ, Yip, AKT and Keenan M (2012) Risk and imagined future: Young adults negotiating and balancing religious and sexual identities. In: Hunt $\mathrm{S}$ and Yip ATK (eds) The Ashgate Research Companion to Contemporary Religion and Sexuality. Farnham: Ashgate.

Puwar N (2001) The Racialised somatic norm and the senior civil service. Sociology, 35(3): 651670.

Riley D (2000) The Words of Selves: Identification, Solidarity, Irony. Stanford: Stanford University Press.

Sharma S (2008) Young women, sexuality and Protestant church community. European Journal of Women's Studies 15(4): 345-59.

Sharma S (2011) Good Girls, Good Sex: Women Talk About Church and Sexuality. Winnipeg, Canada: Fernwood Publishing.

Sharma S and Guest M (2013). Navigating religion between university and home: Christian students' experiences in English universities. Social and Cultural Geography, 14(1): 59-79.

Skeggs B (1997) Formations of Class and Gender: Becoming Respectable. London: Sage Publications.

Skeggs B (2004) Class, Self, Culture. London: Routledge.

Strhan A (2015) Aliens and Strangers?: The Struggle for Coherence in the Everyday Lives of Evangelicals. Oxford: Oxford University Press.

Taragin-Zeller L (2014) Modesty for heaven's sake: Authority and creativity among female ultraOrthodox teenagers in Israel, Nashim: A Journal of Jewish Women's Studies \& Gender Issues, 26: 75-96. 
Tranby E and Hartmann D (2008) Critical whiteness theories and the evangelical "race problem": Extending Emerson and Smith's Divided by Faith. Journal for the Scientific Study of Religion, 47(3): 341-359.

Valentine G (2007) Theorizing and researching intersectionality: A Challenge for feminist geography. The Professional Geographer, 59(1): 10-21.

Winter M, Lummis A \& Stokes A (1994) Defecting in Place: Women Claiming Responsibility for their Own Spiritual Lives. New York: Crossroads.

Woodhead L (2008) Gendering secularization theory. Social Compass 55(2): 187-93.

Yip AKT (2003) The self as the basis of religious faith: Spirituality of gay, lesbian, and bisexual Christians. In: Davie G, Woodhead L and Heelas P (eds), Predicting Religion: Mainstream and Margins in the West London. Farnham: Ashgate.

Yip AKT and Page S (2013) Religious and Sexual Identities. Farnham: Ashgate. 